\title{
FRENKELIA PARASITES IN A SMALL MAMMAL COMMUNITY. DYNAMICS OF INFECTION AND EFFECT ON THE HOST
}

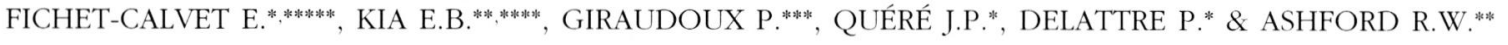

\section{Summary:}

A community of small mammals, Clethrionomys glareolus, Arvicola terrestris, Microtus arvalis, M. agrestis, M. subterraneus, Apodemus spp. and Sorex spp., was studied as hosts of Frenkelia glareoli and F. microti in Franche-Comté (France). They were monitored in spring, summer and autumn on an area of about 1,350 ha comprising open field, hedgerow network and forest. Among 1,714 small mammals examined between July 1992 and October 1993, 47\% $(178 / 376)$ of C. glareolus, $9.9 \%(14 / 139)$ of A. terrestris and $1.3 \%(4 / 311)$ of Apodemus spp. were infected by F. glareoli. The prevalence of infection with $F$. microti was $9.2 \%(60 / 716)$ in $M$. arvalis and $8.2 \%(6 / 73)$ in $M$. agrestis. $M$. subterraneus and Sorex spp. were not infected. The maintenance of each parasite in a rural landscape is assured both by a forest and a grassland host. Multiple logistic regression showed that prevalence was highly agedependent, with an apparent seasonal pattern. Prevalence varied between $30 \%$ in summer and $60 \%$ in early spring for F. glareoli in C. glareolus and between $3 \%$ in autumn to $30 \%$ in early spring for F. microti in M. arvalis. The year, habitat, host sex, relative density had no impact on prevalence. In M. arvalis only, sexually active voles were preferentially uninfected, indicating a possible impact of this parasitism on fertility.

KEY WORDS : voles, population dynamics, Frenkelia spp., Coccidia prevalence, age effect, agroecosystem, mid-mountain.

MOTS CLÉS : campagnol, dynamique de population, Frenkelia spp., coccidie prévalence, effet de l'âge, agroécosystème, moyenne montagne.
Résumé : Des FRENKEIIA CHEZ UN PEUPLEMENT DE PETTS MAMMIFÈRES : DYNAMIQUE DE L'INFESTATION ET IMPACT SUR L'HÔTE L'infestation par Frenkelia glareoli et F. microti a été étudiée au niveau d'un peuplement de petits mammifères composé de Clethrionomys glareolus, Arvicola terrestris, Microtus arvalis, M. agrestis, M. subterraneus, Apodemus spp. et Sorex spp. Les populations ont été suivies au printemps, en été et en automne dans un agroécosystème comprenant des champs ouverts, du bocage et de la forêt. Parmi les 1714 petits mammifères examinés entre juillet 1992 et octobre 1993, 47\% (178/376) des C. glareolus, 9,9\%(14/139) des A. terrestris et 1,3\% $14 / 3111$ des Apodemus spp. étaient infestés par F. glareoli. La prévalence de F. microti était de 9,2\%(66/716) chez M. arvalis et $8,2 \%(6 / 73)$ chez M. agrestis. Aucune infestation n'a été observée chez M. subterraneus et Sorex spp. Dans un tel paysage rural, la maintenance de chaque parasite est assurée par deux hôtes, l'un fréquentant les habitats prairiaux, l'autre les habitats forestiers. Une analyse par régression logistique multiple a montré que les prévalences sont étroitement liées à l'âge de l'hôte alors que les fluctuations saisonnières $130-60 \%$ pour $\mathrm{F}$. glareoli chez C. clethrionomys; $3-30 \%$ pour F. microti chez M. arvalis/ de la prévalence ne sont qu'apparentes et ne dépendent que de la structure en âge de la population hôte. L'année, I'habitat, le sexe de l'hôte et sa densité relative n'ont pas d'influence sur les prévalences. Chez M. arvalis, les individus sexuellement actifs sont préférentiellement ceux qui sont indemnes de F. microti, suggérant ainsi un possible impact de ce parasitisme sur la fertilité de ces rongeurs in natura

\section{INTRODUCTION}

P arasites have long been considered as possible factors in the regulation of rodent populations (Elton et al., 1935). Around 1980, hypothetical

* Centre de biologie et de gestion des populations, Campus de Baillarguet, Montferrier-sur-Lez, France.

** Liverpool school of tropical medicine. United Kingdom.

**** Biologie environnementale EA 3184 usc INRA, Université de Franche-Comté, Besançon, France.

wows School of public health and Institute of public health research, Tehran University of medical sciences, Iran.

*wankat FRE CNRS 2695 "Origine, structure et évolution de la biodiversité", Laboratoire mammifères \& oiseaux, Muséum national d'histoire naturelle, Paris, France

Correspondence : Dr Elisabeth Fichet-Calvet, FRE CNRS 2695 "Origine, structure et évolution de la biodiversité", Laboratoire mammifères \& oiseaux, Muséum national d'histoire naturelle, 55, rue Buffon, 75005 Paris. France.

Tel.: 33 (0)1 40793069 - Fax : 33 (0)1 40793063 .

E-mail: calvet $(1 \mathrm{mnhn}$.fr models were produced, considering host-parasite systems as a special case of predator-prey interaction (Anderson \& May, 1978; Holmes, 1982). Paradoxically, very few studies in nature have tested these models. This was true long ago (Wiger, 1977), and there have been few relevant studies since that time. Ecological studies on the effects of parasites on host populations are particularly appropriate in the applied study of the management of irruptive rodent species (Jäkel et al., 1999). We have carried out a long-term study of agricultural pest rodents in mid-mountain zones in France (Delattre et al., 1992, 1996, 1999), and have previously linked a study of the cestode parasites of these rodents (Giraudoux, 1991; Le Pesteur et al., 1992). Additional results are presented here, on the protozoan parasites Frenkelia spp., of the brains of these rodents. Frenkelia microti was first discovered (As "M organism", thought to be closely related to Toxoplasma) in Wales, 
by Findlay \& Middleton (1934), in Microtus agrestis at the time of a population crash.

Frenkelia spp are heteroxenous coccidia with sexual reproduction in the intestines of birds of prey, especially the Buzzard Buteo buteo, and asexual multiplication in the brains of rodents. The full life history was first described, for F. glareoli in the bank vole, Clethrionomys glareolus, by Rommel \& Krampitz (1975). Resistant sporocysts are excreted in the faeces of Buzzards from 7-9 days following infection, for a period of 7-57 days. Sporozoites emerge from the sporocysts when these are ingested by a rodent, and migrate to the brain, where they produce cysts that are visible 17 to 18 days following infection (Geisel et al., 1978; Laarman et al., 1979). Over a period of weeks, the cysts grow to $350 \mu \mathrm{m}$ in diameter, and contain many thousand bradyzoites, which are infective to Buzzards when the rodent host is eaten. Heavily infected rodents contain numerous cysts, which occupy a considerable proportion of all parts of the brain, and infection lasts for the life of the host (Tadros \& Laarman, 1976; Laarman et al., 1979). The earliest age at which the rodents can be infected is unknown.

Two species of Frenkelia are known to occur in Europe, $F$. glareoli, mainly in C. glareolus, and F. microti, mainly in Microtus spp. (Tadros \& Laarman, 1982).

Vorisek et al. (1998) have shown evidence that infected rodents are more likely to be predated than uninfected individuals, as happens in certain other host-parasite combinations (review by Combes, 1995). Transmission of the parasite is thereby facilitated, and the longevity of infected rodents is reduced. Reduced longevity of some individuals does not necessarily have any regulatory effect on populations. In order to assess any regulatory effect of the parasite on intermediate host populations, information is first required on the distribution of the parasite in the host community at a local scale.

The aim of this study is to test for any effect of extrinsic (year, season, habitat) and intrinsic (host age, sex and relative density) factors on the infection rates in each species of the rodent community. Then, the possibility of an effect of the parasites on the hosts was investigated by comparing the body weight and sexual activity of infected and uninfected individuals.

\section{MATERIALS AND METHODS}

\section{STUDY SITE}

T The study area occupies about 1,350 ha, in Franche-Comté, $10 \mathrm{~km}$ north-west of Pontarlier $\left(47.10^{\circ} \mathrm{N}, 6.24^{\circ} \mathrm{E}, 850 \mathrm{~m}\right.$ above sea level) with mean annual rainfall of $1,500 \mathrm{~mm}$. The landscape is

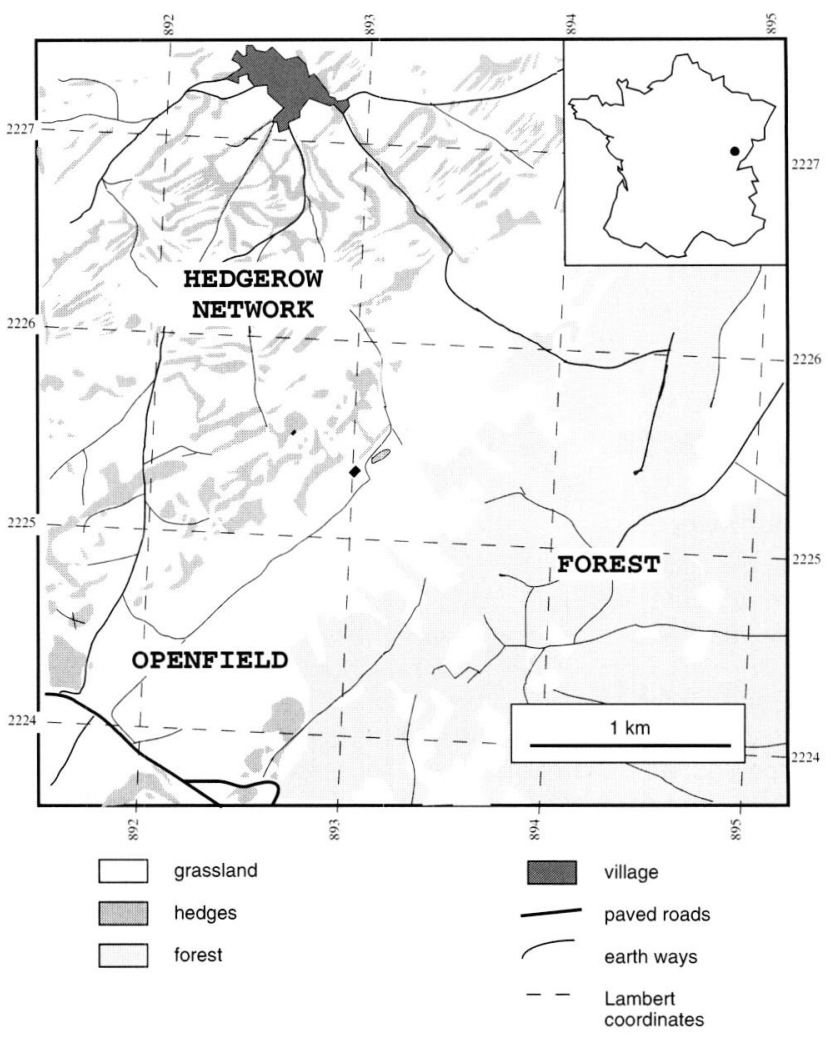

Fig. 1. - Landscape composition of the study site located in the Jura plateau.

composed of forest and agricultural land. The forest is mostly semi-natural, composed of mixed beech Fagus sylvatica, oak Quercus robur, and fir Abies alba, and there are some spruce Picea abies plantations. The agricultural land is either improved grassland or permanent pasture (Delattre et al., 1988; Giraudoux et al., 1997), and is either, open over wide areas (open field), or enclosed by hedgerows in plots of $c a 1$ ha (Fig. 1).

\section{TRAPPING AND SAMPLING}

Trapping was carried out in forest (deciduous, mixed, coniferous), hedgerow network (hedge, hedge edge, enclosures) and open field (permanent grassland) habitats. Because this study is part of a rodent survey for outbreak management, small mammals were sampled during the reproduction period: in July and October 1992, and April, July and October 1993. INRA (French Agronomic Research Institute) trap lines were used (Spitz et al., 1974). Thirty-four traps were placed at $3 \mathrm{~m}$ intervals in each line of about $100 \mathrm{~m}$. The numbers of lines set on each occasion, and the distribution by habitat of the 214 trap lines (21,828 trap nights) are shown in Table I. Traps were left in place for three consecutive nights, and were visited twice daily. Animals were killed by cervical dislocation according to Mills et al. (1995). 


\begin{tabular}{cccccc}
\hline & Habitat & Jul 92 & Oct 92 & Apr 93 & Jul 93 \\
\hline Species & Forest & $\begin{array}{l}\text { deciduous } \\
\text { mixed } \\
\text { coniferous }\end{array}$ & 0 & $22\left\{\begin{array}{l}5+1^{*} \\
3 \\
13\end{array}\right.$ & $21\left\{\begin{array}{l}1 \\
6 \\
14\end{array}\right.$ \\
\hline
\end{tabular}

Table I. - Distribution of the 214 trap lines by habitat and by season. Arrows design the habitats in which the rodent ralative abundances are calculated. " corresponds to a forest clearing.

\section{HOST POPULATION PARAMETERS}

Relative abundance was estimated for each species as the number caught per trap line. For C. glareolus, captures in forest and in hedgerow network were analysed separately. For Microtus arvalis, captures in hedgerow network and in open field were analysed separately. For Microtus agrestis, which was less abundant, captures in forest and in hedgerow network were combined. Arvicola terrestris numbers were not estimated as only juveniles were sampled, adults being too big to enter the traps.

The weight of the desiccated eye lens (ELW) gives the best indication of age for small mammals (Lord, 1959; Martinet, 1966, rev. in Morris, 1971). Eyes were removed and preserved for a minimum of two weeks in $10 \%$ formalin, then the lenses were extracted, dried for two hours at $100^{\circ} \mathrm{C}$, and weighed to a precision of $0.1 \mathrm{mg}$. Females were classified as sexually active if they were pregnant or lactating, as were males with seminal vesicles over $40 \mathrm{~mm}^{2}$ (length $\times$ breadth). Litter size was estimated by the number of embryos.

\section{PARASITES}

Carcasses were preserved in $10 \%$ formalin before examination. The brain was removed by dissection of the skull, and stained for at least $24 \mathrm{~h}$ in undiluted Semichon's acetic carmine. They were then washed in distilled water, transferred to $1 \% \mathrm{HCl}$ in $70 \%$ ethanol to differentiate, until the brain material was very pale pink in colour (usually a few hours), and placed in glycerine to clear. The stained, cleared brains were then sliced with a scalpel and the slices were examined with a dissecting microscope $(\times 100)$ to detect any parasites. Lobulated cysts were identified as F. microti, and large round cysts as F. glareoli (Tadros et al., 1972; Tadros \& Laarman, 1978). A few very small round cysts were regarded as unidentifiable except in juvenile A. terrestris in which $2 / 102$ were Toxoplasma gondii, and 3/102 were Frenkelia, glareoli (Kia et al., in press).

\section{STATISTICAL ANALYSIS}

Year, season, habitat, host sex, age and relative density effects on prevalence were analysed with a multiple logistic regression using a binary factor (infected $=1$, non infected $=0$ ) as the dependent variable and year (two levels: 1992, 1993), season (three levels: spring, summer and autumn), habitat (three levels: open field, hedgerow network and forest), host sex (two levels), host age (continuous ELW) and host relative density (continuous abundance index) as independent variables. The strategy of data treatment was first to enter all the variables in a global model, and to perform a forward stepwise regression to select the non redundant variables. The second stage was to enter these selected variables with their interactions in a restricted model as recommended by Kleinbaum \& Klein (2002). This analysis was performed with Systat 9, SAS Institute Inc. (1999).

The effect of infection on weight was analysed using ANCOVA with weight as the dependent variable and the host sex and infection (two levels: infected, uninfected) as the independent variables. Host age (continuous ELW) was entered as the covariate in the model. The effect of infection on sexual activity was analysed using multiple logistic regression including sexual activity (active $=1$, inactive $=0$ ) as the dependent variable and the infection (two levels: infected, uninfected), year (two levels), season (three levels), habitat (three levels), host sex, host age (continuous ELW) and host relative density (continuous abundance index) as the independent variables. As the goal of this analysis was to obtain a single estimate of the Frenkelia infection, adjusted for year, season, habitat, host sex, host age, and host relative density, the interactions were not included in the model (Kleinbaum \& Klein, 2002). The effect of infection on fertility in each sex was analysed using ANCOVA with seminal vesicle size or litter size as the dependent variable and infection (two levels: infected, uninfected), season (three levels) and host age (continuous ELW) as independent variables (Legendre \& Legendre, 1998; Sokal \& Rohlf, 1998). 


\section{RESULTS}

\section{HOST RANGE}

C f 2,848 animals collected, 1,714 were examined for Frenkelia infection (Table II). F. glareoli was mainly found in C. glareoli, secondarily in Arvicola terrestris, and rarely in M. arvalis, M. agrestis and Apodemus spp. F. microti was most frequent in $M$. arvalis and $M$. agrestis and was also found rarely in C. glareolus. Microtus subterraneus and Sorex spp were never found infected.

Further analysis is restricted to the infection in the four most important hosts, C. glareolus, A. terrestris, M. arvalis and $M$. agrestis.

\section{PREVALENCE}

\section{- Frenkelia glareoli in Clethrionomys glareolus}

The influence of year, season, habitat, host sex, age and relative density on prevalence was analysed in a global model by forward stepwise regression. The main effect on prevalence was due to host age $\left(\mathrm{chi}^{2}=19.204, \mathrm{p}<\right.$ 0.0001 ), whereas the other factors were not significant Host age is highly significant with an odds ratio of 1.043 $(\mathrm{p}<0.0001)$, indicating an increase of prevalence with

\begin{tabular}{lcccc}
\hline \multicolumn{1}{c}{ Host species } & No. collected & No. examined & F. glareoli $(\%)$ & F. microti $(\%)$ \\
\hline Cletbrionomys glareolus & 537 & 376 & $178(47)$ & $3(1)$ \\
Arvicola terrestris & 210 & 139 & $14(9.9)$ & 0 \\
Microtus arvalis & 981 & 716 & $1(2)$ & $66(9.2)$ \\
Microtus agrestis & 136 & 73 & $1(1.4)$ & $6(8.2)$ \\
Microtus subterraneus & 20 & 12 & 0 & 0 \\
Apodemus spp. ${ }^{1}$ & 761 & 311 & $4(1.3)$ & 0 \\
Sorex spp. & 203 & 87 & 0 & 0 \\
\hline
\end{tabular}

${ }^{1}$ Apodemus flavicollis predominated, but A. sylvaticus also occurred; no attempt was made to distinguish juvenile specimens, so both species are grouped together. ${ }^{2}$ Sorex coronatus and $S$. araneus were not distinguished for the present study

Table II. - Prevalences and host range in a small mammal community infected by Frenkelia glareoli and F. microti.

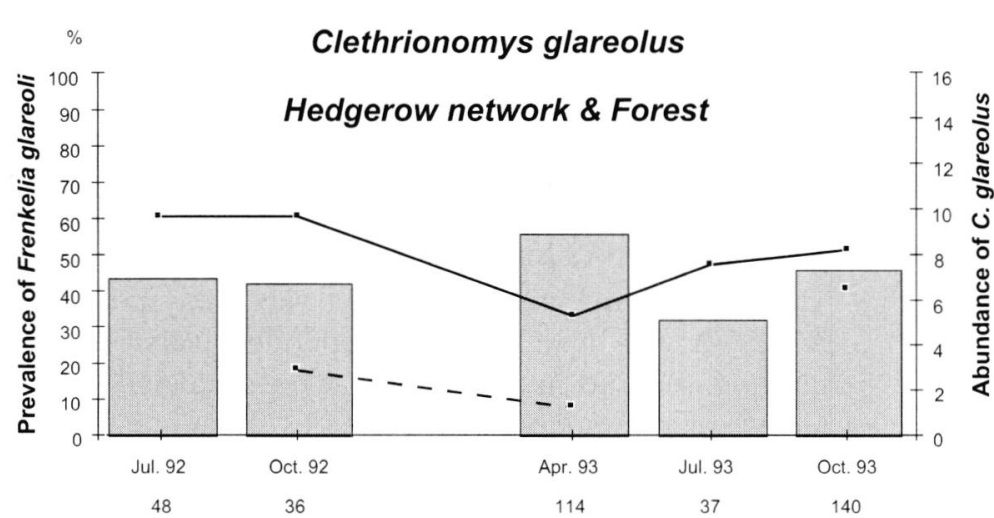

Frenkelia glareoli in Clethrionomys glareolus

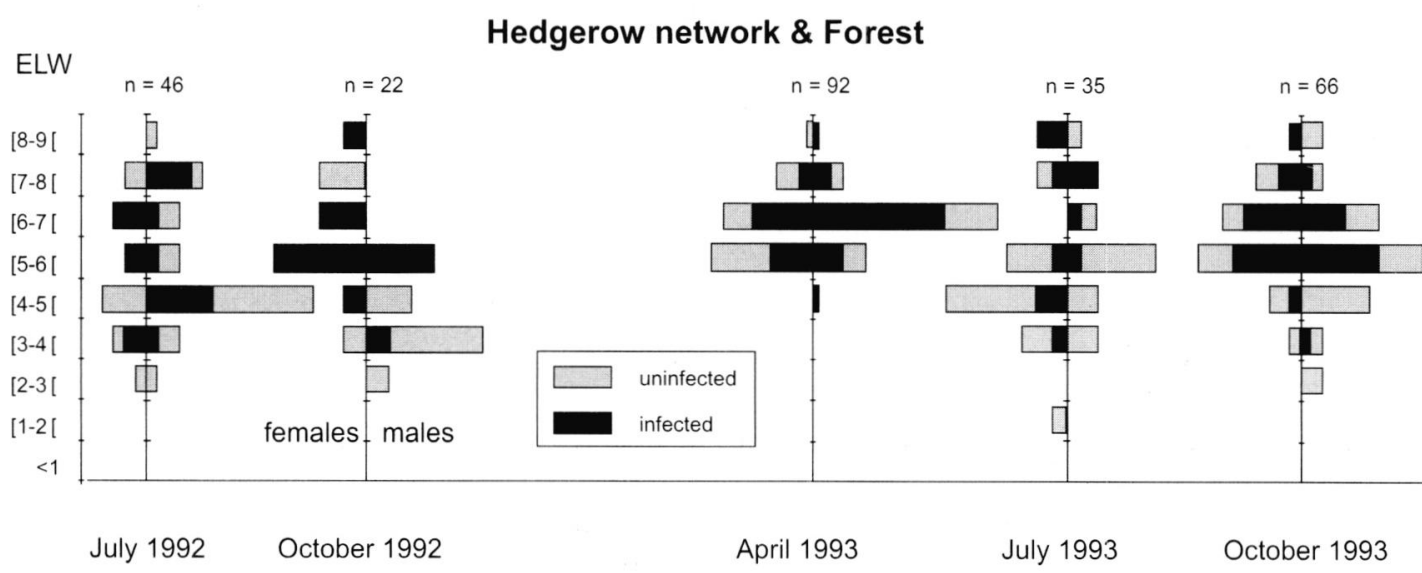

Fig. 3. - Distribution of Frenkelia glareoli in Clethrionomys glareolus by eye lens weight (ELW in $\mathrm{mg}$ ) and sex of host. 
age. The host age effect is illustrated in Figure 3 where the age structure is presented for each session. Infected individuals were present at each session and in each ELW class over $3 \mathrm{mg}$. Prevalence remained high throughout the year (Fig. 2) with the lowest prevalence in July 1993 (32\%) and the highest in April 1993 (62\%). These seasonal variations were not significant when host age was taken into account. The model explains only $4 \%(250.475-240.577 / 250.475)$ of the total variation, suggesting that many other factors than host age explain $96 \%$ of the variation of prevalence of $F$. glareoli in C. glareolus.

\section{- Frenkelia glareoli in Arvicola terrestris}

Because $A$. terrestris were captured almost exclusively in enclosed grassland, the variable "habitat" was excluded from this analysis. In addition, relative density of this species was not evaluated since only juvenile specimens were caught. Among the four remaining variables, year, season, host sex and host age $(1.6 \leq \mathrm{ELW} \leq 11.1)$, the multiple logistic regression shows that only the two last had an effect on prevalence $\left(\mathrm{Chi}^{2}=3.983, \mathrm{p}=0.046\right.$ and $\mathrm{Chi}^{2}=21.200, \mathrm{p}<0.0001$ respectively). Infection was twice as common in females $(8 / 61)$ than in males $(4 / 58)$.

\section{- Frenkelia microti in Microtus arvalis}

First, the forward stepwise regression showed host age, relative density, and year to be significant variables having an effect on the Frenkelia infection. The other variables, season, host sex and habitat, were not correlated with prevalence. Host age is highly significant with an odds ratio of 1.069 ( $p<0.0001$ ), indicating increasing infection with age. This effect is illustrated in Figure 5 where the age structure is presented for each session. Infected individuals were present at each session, with very young ones in summer with ELW between 2 and $3 \mathrm{mg}$. In autumn, the youngest infected vole had ELW over $3.5 \mathrm{mg}$. Host relative density is significant with an odds ratio of $0.807(\mathrm{p}<0.001)$ indicating that the prevalence of $F$. microti is negatively correlated with the abundance of its host. The year effect is described by an OR of 0.635 indicating a lower prevalence in 1993 than 1992. Figure 4 shows prevalence to be highest in spring (29\% in April 1993), when the vole population was at its lowest; prevalence declined in the breeding season (17\% in July 1992; $3 \%$ in July 1993), reaching its lowest in autumn (7\% in October 1992; $3 \%$ in October 1993), when the host population was at its greatest. These seasonal variations were not significant when host age was taken into account. In the restricted model containing the main factors, host age, host relative density and year, and their interactions, the 2 -way interactions, i.e., "year $\times$ host relative density" and the 3 -way interaction "year $x$ host age $\times$ host density" were significant, whereas the main factor turned to non-significant (Table III). This means

\begin{tabular}{lrcc}
\hline \multicolumn{1}{c}{ Variables } & $\mathbf{C h i}^{2}$ & $\begin{array}{r}\text { Residual } \\
\text { deviance }\end{array}$ & p \\
\hline Null & & 208.882 & \\
Host age $(1.2 \leq \mathrm{elw} \leq 7.5)$ & 60.084 & 181.277 & $<0.0001$ \\
Host relative density $(2.8 \leq$ ai $\leq 14.4)$ & 20.610 & 169.946 & $<0.0001$ \\
Host age $\times$ host relative density & 8.083 & 165.854 & 0.004 \\
Year $\times$ host relative density & 4.462 & 163.815 & 0.035 \\
Year $\times$ host age $\times$ host relative density & 3.969 & 161.922 & 0.046 \\
Year $\times$ host age & 0.093 & 161.922 & 0.761 \\
Year & 0.028 & 161.922 & 0.868 \\
\hline
\end{tabular}

Table III. - Logistic regression results for Frenkelia microti infection in Microtus arvalis in a hedgerow network (HNW) and open field model. $\mathrm{Elw}=$ eye lens weight in $\mathrm{mg}$, ai = abundance index in number of voles trapped per $100 \mathrm{~m} . \mathrm{n}=670$.

that these variables were not additive, and also that the combined effect of host age and host density on prevalence has to be considered year by year. This restricted model explains $22 \%(208.882-161.922 / 208.882)$ of the total variation, suggesting that other factors are involved in Frenkelia infection in $M$. arvalis.

\section{- Frenkelia microti in Microtus agrestis}

As the M. agrestis sample was not large enough to segregate captures between hedgerow network and forest, the data were pooled, and habitat was excluded from the model. Here, the main effect on infection is due to host age only $\left(\mathrm{Chi}^{2}=7.851, \mathrm{p}=0.005\right)$ whereas year, season, host sex and relative density are not significant.

\section{EFFECT OF PARASITES ON WEIGHT AND SEXUAL ACTIVITY OF THE HOST}

To assess the possible impact of parasitism on weight and sexual activity in rodents, infection in the two numerous and well sampled hosts, C. glareolus and M. arvalis was analysed.

\section{- Frenkelia glareoli in C. glareolus}

Table IV shows the effect of $F$. glareoli infection on the weight of C. glareolus with season, host sex and

\begin{tabular}{|c|c|c|c|c|}
\hline \multirow[b]{2}{*}{ Source of variation } & \multicolumn{2}{|c|}{$\begin{array}{l}\text { C. glareolus } \\
\text { model }\end{array}$} & \multicolumn{2}{|c|}{$\begin{array}{l}\text { M. arvalis } \\
\text { model }\end{array}$} \\
\hline & F & $\mathrm{p}$ & $\mathrm{F}$ & $\mathrm{p}$ \\
\hline Host infection & 0.019 & 0.889 & 0.583 & 0.445 \\
\hline Host sex & 9.857 & 0.002 & 13.991 & 0.0002 \\
\hline Season & 36.474 & $<0.0001$ & 131.277 & $<0.0001$ \\
\hline Infection $\times$ sex & 0.882 & 0.348 & 4.749 & 0.297 \\
\hline Infection $\times$ season & 4.649 & 0.010 & 1.421 & 0.242 \\
\hline Sex $\times$ season & 26.024 & $<0.0001$ & 4.672 & 0.009 \\
\hline Infection $\times$ sex $\times$ season & 0.668 & 0.513 & 0.856 & 0.425 \\
\hline Host age (elw) & 184.219 & $<0.0001$ & 546.805 & $<0.0001$ \\
\hline
\end{tabular}

Table IV. - Intrinsic and extrinsic sources of variation in the body weight in Clethrionomys glareolus infected with Frenkelia glareoli and in Microtus arvalis infected with Frenkelia microti through ANCOVA. Host age, estimated by the eye lens weight (elw), is entered as a covariate in each model. 


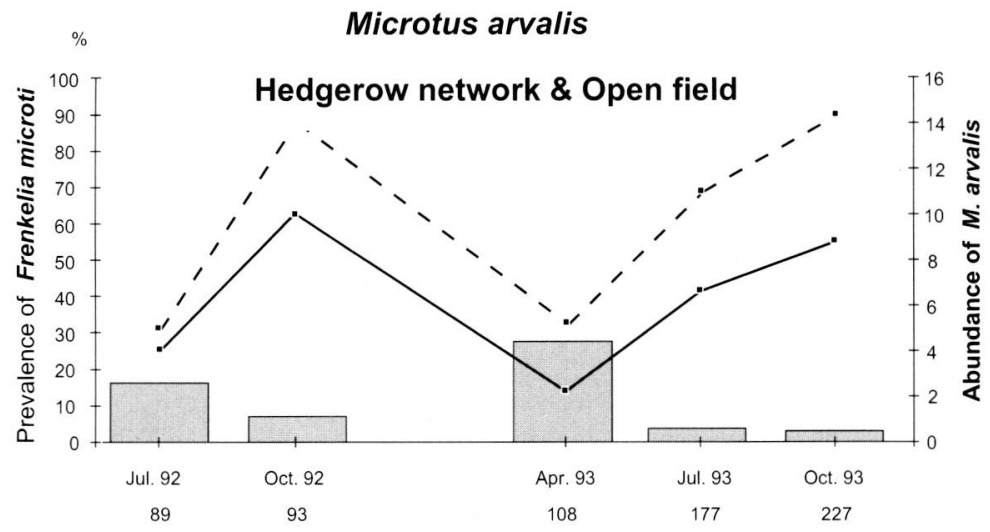

prevalence

_ host abundance in hedgerow network

- $\quad$ host abundance in open field

Fig. 4. - Prevalence of Frenkelia microti and abundance of its host Microtus arvalis (number of captures per $100 \mathrm{~m}$ of trap line) in the hedgerow network and in the open field habitats. Numbers under each bar correspond to the rodents examined for infection.

Frenkelia microti in Microtus arvalis

Hedgerow network \& Open field

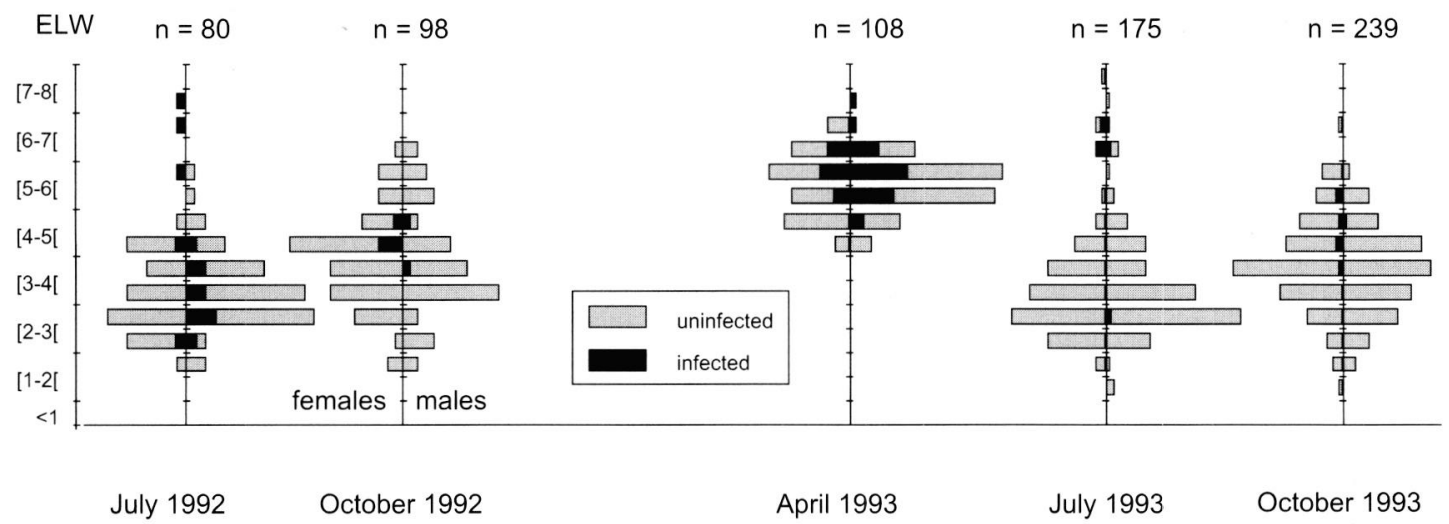

Fig. 5. - Distribution of Frenkelia microti in Microtus arvalis by eye lens weight (ELW in $\mathrm{mg}$ ) and sex of host.

age taken into account through ANCOVA. Weight is significantly affected by age, sex and season but not by Frenkelia infection. The two way interaction, infection $\times$ season, is significant. This is illustrated in Figure 6

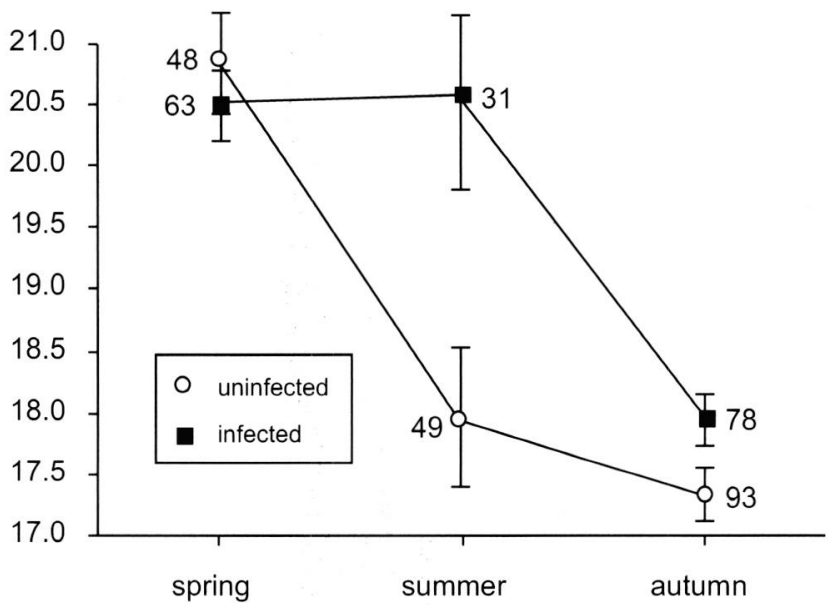

Fig. 6. - Mean body weight (in g with standard error bars) in infected and uninfected Clethrionomys glareolus, by season. Number close to each symbol indicates the sample size. showing that, in summer, the infected voles are heavier than the uninfected ones.

Using multiple logistic regression, sexual activity in both sexes is significantly correlated with year, season, host sex and age, but not with habitat, relative density or Frenkelia infection (Table V). For males, the length $\times$ breadth of the seminal vesicles is highly correlated with host age $\left(\mathrm{F}_{1,200}=58.980, \mathrm{p}<0.0001\right)$ and

\begin{tabular}{|c|c|c|c|c|}
\hline \multirow[b]{2}{*}{ Variables } & \multicolumn{2}{|c|}{$\begin{array}{c}\text { C. glareolus } \\
\text { model }\end{array}$} & \multicolumn{2}{|c|}{$\begin{array}{l}\text { M. arvalis } \\
\text { model }\end{array}$} \\
\hline & $\mathrm{Chi}^{2}$ & $\mathrm{p}$ & $\mathrm{Chi}^{2}$ & $\mathrm{p}$ \\
\hline Infection & 0.200 & 0.655 & 6.205 & 0.013 \\
\hline Year & 3.980 & 0.046 & 32.940 & $<0.0001$ \\
\hline Season & 18.867 & $<0.0001$ & 97.888 & $<0.0001$ \\
\hline Habitat & 0.151 & 0.697 & 17.105 & $<0.0001$ \\
\hline Host sex & 16.044 & $<0.0001$ & 0.470 & 0.493 \\
\hline Host age & 16.578 & $<0.0001$ & 42.791 & $<0.0001$ \\
\hline Host relative density & 0.145 & 0.703 & 11.802 & 0.0006 \\
\hline
\end{tabular}

Table V. - Logistic regression results for sexual activity in Clethionomys glareolus infected with Frenkelia glareoli and in Microtus arvalis infected with Frenkelia microti. 
season $\left(\mathrm{F}_{2,200}=53.222, \mathrm{p}<0.0001\right)$ but not with Frenkelia infection $\left(\mathrm{F}_{1,200}=2.506, \mathrm{p}=0.115\right)$. There were insufficient pregnant females in the sample to test for differences in litter size.

\section{- Frenkelia microti in M. arvalis}

The same analysis as above shows that the variation in weight of $M$. arvalis was mainly due to host age and sex, and to season, but not to Frenkelia infection. The significant two way interaction, season $\times$ host sex, is due to the increased weight of females in autumn (Table IV).

The sexual activity in $M$. arvalis also showed a multifactorial dependency pattern, significantly correlated with year, season, host age, relative density, habitat and infection (Table V). The most interesting correlations are those concerning habitat and Frenkelia infection. Their partial coefficients show that open field and infection are negatively correlated with sexual activity $(\mathrm{r}=-0.131, \mathrm{p}<0.0001$ and $\mathrm{r}=-0.069, \mathrm{p}=0.014$ respectively). This suggests a lower sexual activity in open field than in hedgerow network, and in infected voles than in uninfected ones. Seminal vesicle size was not influenced by Frenkelia infection $\left(\mathrm{F}_{1.359}=0.949\right.$, $\mathrm{p}=0.330)$ but only by age $\left(\mathrm{F}_{1.359}=102.341, \mathrm{p}<0.0001\right)$ and season $\left(\mathrm{F}_{2.359}=22.567, \mathrm{p}<0.0001\right)$. Litter size was related to the season only $\left(\mathrm{F}_{2,91}=10.478, \mathrm{p}<0.0001\right)$ but not to Frenkelia infection $\left(\mathrm{F}_{1,91}=0.022, \mathrm{p}=0.871\right)$.

\section{DISCUSSION}

\section{OCCURRENCE OF FRENKELIA SPP. IN INTERMEDIATE HOSTS}

The main host for $F$. glareoli is clearly $C$.glareolus, with almost $50 \%$ prevalence overall. The other important host for this species is A. terrestris, which appears to be a new host record. Bearing in mind the fact that only juvenile animals of this species were sampled, the
$10 \%$ prevalence is probably an underestimate of the real prevalence.

Apodemus spp, Microtus arvalis and M. agrestris are incidental hosts, with low prevalence of infection. A similar result was found in the Czech Republic by Vorisek et al. (1998). It is not clear whether these low prevalences are due to innate resistance in most individuals, lower exposure to infection (unlikely for Microtus spp, as these are infected with F. microti which has the same transmission mechanism), or high mortality of infected animals. The main hosts of $F$. microti are confirmed to be $M$. arvalis (9\% prevalence) and $M$. agrestis ( $8 \%$ prevalence). C. glareolus is clearly an incidental host for this parasite.

This study shows that each of the Frenkelia species is maintained by two main intermediate hosts, which inhabit wooded habitats such as forest or hedges in hedgerow network, and grassland such as open field or fields in hedgerow network.

\section{VARIATIONS IN PREVALENCE}

Host age is the main factor influencing the prevalence of Frenkelia in voles (Table VI). This positive relation has been pointed out in rodents infected with many parasites such as cestodes (Behnke et al., 1993, 1999), trematodes (Duplantier \& Sène, 2000), protozoa (Turner, 1986), bacteria (Godeluck et al., 1994; FichetCalvet et al., 2000) and viruses (Mills et al., 1992). These results suggest that as the rodents age, the probability of infection increases. In $M$. arvalis, the infection can occur very early in its life, around 20-30 days in summer. This age was extrapolated from the ELW measures of captive-bred animals (Martinet, 1966). In C. glareolus, host age is the only factor correlated with the prevalence of $F$. glareoli whereas year and host relative density also showed a distinct influence on the prevalence of $F$. microti in $M$. arvalis. F. microti was more prevalent in 1992 than 1993 and during this time, the density of $M$. arvalis was stable. As the buzzard population declined in 1993 (pers. obs.), it is suggested

\begin{tabular}{|c|c|c|c|c|c|c|}
\hline \multirow{2}{*}{$\begin{array}{c}\text { Source } \\
\text { of variation }\end{array}$} & \multicolumn{4}{|c|}{ Prevalence } & \multicolumn{2}{|c|}{ Sexual activity } \\
\hline & $\mathrm{Fg}$ in $\mathrm{Cg}$ & $\mathrm{Fg}$ in $\mathrm{At}$ & $\mathrm{Fm}$ in $\mathrm{Ma}$ & $F m$ in $M g$ & $\mathrm{Cg}$ & $\mathrm{Ma}$ \\
\hline Year & 0 & 0 & $-(1993)$ & 0 & $-(1993)$ & $-(1993)$ \\
\hline Season & 0 & 0 & 0 & 0 & + (spring \& summer) & + (spring \& summer) \\
\hline Habitat & 0 & NI & 0 & NI & 0 & - (Open Field $)$ \\
\hline Host sex & 0 & $+($ female $)$ & 0 & 0 & $+($ male $)$ & 0 \\
\hline Host age & + & + & + & + & + & + \\
\hline Host relative density & 0 & NI & - & 0 & 0 & + \\
\hline Infection & & & & & 0 & - (infected) \\
\hline
\end{tabular}

Table VI. - Summarized effects variables on the prevalence of Frenkelia infection and on sexual activity. $0=$ not significant, + positive, - negative. Information between brackets indicates which level is source of variation for nominal factors. Fg $=$ Frenkelia glareoli, Fm $=$ Frenkelia microti, $\mathrm{Cg}=$ Clethrionomys glareolus, $\mathrm{At}=$ Arvicola terrestris, $\mathrm{Ma}=$ Microtus arvalis, $\mathrm{Mg}=$ Microtus agrestis. $\mathrm{NI}=\mathrm{non}$ included. 
that the reduction in prevalence may be related to the decrease in density of buzzards. The negative correlation between prevalence and host relative density indicates that when the voles are most numerous, the infection rate is lowest. The buzzard is a common predator of the two voles, but the density effect is not discernible in C. glareolus, probably because of the relative stability of their population.

Even though prevalence fluctuates seasonally, season has no impact on prevalence when host age is taken into account. In spring, when the population of $C$. glareolus and $M$. arvalis was at its minimum, consisting only of old adults that had survived the winter, prevalence of both Frenkelia spp. was maximal ( $F$. glareoli: $62 \%$, F. microti: $29 \%$ ). Infected animals were then diluted by newly born individuals between spring and autumn and, as the older individuals died off, overall prevalence declined ( $F$. glareoli: $32 \%, F$. microti: $3 \%$ ). These findings agree with those of Laarman et al. (1979) in the Netherlands where, in winter and early spring, most of bank voles were infected whereas only 25-30\% were infected in summer. In the Czech Republic, Vorisek et al. (1998) found a mean prevalence of $16 \%$ in spring which is similar to that observed here in the $C$. glareolus living in forest. The declining prevalence of $F$. microti between July and October is explicable partly by the extension of the breeding season into the autumn, and continuing dilution with young individuals.

The data suggest that F. microti and F. glareoli are equally transmitted all through the year. The high prevalence of $F$. glareoli in young of both $C$. glareolus in July and $A$. terrestris in April, indicating a high rate of transmission in spring and early summer, supports this hypothesis.

In M. agrestis, the prevalence of F. microti in April 1993 (22\%) was greater than that observed in Finland $(6 \%)$ in the same season (Soveri et al., 2000). In the winter of 1992-1993, buzzards were unusually abundant on the Jura plateau, which may explain this difference.

Habitat had no impact on the prevalence of Frenkelia spp. The bank voles were equally infected in hedgerow network as in the forest. The irregularity of the forest boundaries and clearings make the forest a mosaic where the permeability of the parasite is equal to that in the hedgerow network. A comparative study in a landscape with larger areas of unbroken forest would be necessary to show any impact of habitat on prevalence. Infection in Microtus spp. is equally prevalent in enclosed and open grassland and, here again, a larger open field would be necessary to show any impact of the habitat in relation to the behaviour of the buzzard, which spends more time on open than closed habitats.

\section{EFFECTS OF PARASITES ON HOST WEIGHT AND SEXUAL ACTIVITY}

In the overall samples, when animals of all ages were represented, and before correcting for age, infected voles of both species were systematically heavier than uninfected individuals (C. glareolus: $19.3 \pm 3.1 \mathrm{~g}, \mathrm{n}=$ 172 vs $18.3 \pm 3.5 \mathrm{~g}, \mathrm{n}=190 ; M$. arvalis: $21.6 \pm 6.3 \mathrm{~g}$, $\mathrm{n}=63$ us $18.2 \pm 6.2 \mathrm{~g}, \mathrm{n}=607)$. For C. glareoli infected by $F$. glareoli, this trend was particularly true in summer when voles were reproducing. Hoogenboom \& Dijkstra (1987) found a similar effect in another heteroxenous coccidian in the muscles of $M$. arvalis, Sarcocystis cernae, in which infection was associated with increased weight, but this study was not fully adjusted for age, and older, heavier animals are more likely to be infected. When the sample is restricted to similar season and age cohort, as for Psammomys obesus infected with Bartonella spp. or Babesia spp. in Tunisia, the weight is equal in, infected and uninfected animals (Fichet-Calvet et al., 2000). In our study, infection with Frenkelia spp. had no impact on body weight when season, sex and age were taken into account. These last three factors are normally the main determinants of body weight. More interesting are the results concerning sexual activity, which also depends on season and age (Table VI). Sexual activity was also dependent on year, with a higher probability of inactivity in 1993. This lack of sexual activity could explain why the M. arvalis population crashed in 1994 following a period of high density lasting three years (unpublished data). $M$. arvalis was less sexually active in open field than in hedgerow network, indicating that the crash began in open field before continuing in hedgerow network. Sexual activity was positively related with density, reflecting continuation of reproduction into the autumn and an accumulation of several cohorts born in the previous spring and summer when $M$. arvalis was abundant. In males, the infection was not correlated with the size of the seminal vesicles. In pregnant females, the infection did not affect the litter size. However, infected individuals of $M$. arvalis were less sexually active than uninfected ones. This suggests that $F$. microti may delay female sexual maturity. Mechanisms such as a delay in the first pregnancy or an increasing time between litters have been shown in C. glareolus infected with cowpox virus in UK (Feore et al., 1997). Our result is consistent with a possible regulation of host population by parasitism. An additional regulatory effect on the intermediate host populations could operate through an increased risk of predation leading to reduced longevity and a reduced number of litters produced by predated individuals. Against this, there is no evidence of reduced prevalence in the oldest animals, indicating that longevity is not reduced in infected individuals. 


\section{ACKNOWLEDGEMENTS}

$\mathrm{F}$ inancial support of the Franche-Comté regional council is gratefully acknowledged. E. F-C. benefited from a grant from the Société de Secours des Amis des Sciences (Paris). Many thanks to the Réseau d'Observation Prédateurs-Rongeurs-Environnement for providing data on buzzard dynamics. The authors are grateful to J-M. Duplantier for his useful comments on the earlier version of the manuscript.

\section{REFERENCES}

Anderson R.M. \& MAY R.M. Regulation and stability of hostparasite population interactions. I. Regulatory processes. Journal of Animal Ecology, 1978, 47, 219-247.

Behnke J.M., Barnard C., Hurst J.L., McGregor P.K., GilBERT F. \& LEWIS J.W. The prevalence and intensity of infection with helminth parasites in Mus spretus from the Setubal Peninsula of Portugal. Journal of Helmintbology, 1993, 67, 115-122.

Behnke J.M., Lewis J.W., Mohd Zain S.N. \& Gilbert F.S. Helminth infections in Apodemus sylvaticus in southern England: interactive effects of host age, sex and year on the prevalence and abundance of infections. Journal of Helmintbology, 1999, 73, 31-44.

Combes C. Interactions durables. Écologie et évolution du parasitisme. Masson, Paris, 1995.

Delattre P., Pascal M., Le Pesteur M.H., Giraldoux P. \& Damange J.P. Caractéristiques écologiques et épidémiologiques de l'Echinococcus multilocularis au cours d'un cycle complet des populations d'un hôte intermédiaire (Microtus arvalis). Canadian Journal of Zoology, 1988, 66, 2740-2750.

Delattre P., Giraudoux P., Baudry J., Musard P., Toussaint M., Truchetet D., Stahl P., Lazarine-Polle M., Artois M., Damange J.P. \& Quéré J.P. Land use patterns and types of common vole (Microtus arvalis) population kinetics. Agriculture, Ecosystem and Environment, 1992, 39, 153-169.

Delattre P., Giraudoux P., Baudry J., Quéré J.P. \& Fichet E. Effect of landscape structure on Common Vole (Microtus arvalis) distribution and abundance at several space scales. Landscape Ecology, 1996, 11, 279-288.

Delattre P., De Sousa B., Fichet-Calvet E., Quéré J.P. \& Giraudoux P. Vole outbreaks in a landscape context: evidence from a six year study of Microtus arvalis. Landscape Ecology, 1999, 14, 401-412.

Duplantier J.M. \& SÈnE M. Rodents as reservoir hosts in the transmission of Schistosoma mansoni in Richard-Toll, Senegal, West Africa. Journal of Helmintbology, 2000, 74, 129-135.

Feore S.M., Bennett M., Chantrey J., Jones T., Baxby D. \& BEGON M. The effect of cowpox virus infection on fecundity in bank voles and wood mice. Proceedings of the Royal Society of London. Series B. Biological Sciences, 1997, 264, 1457-1461.

Fichet-Calvet E., Jomâa I., Ben Ismail R. \& Ashford R.W. Patterns of infection of haemoparasites in the fat sand rat,
Psammomys obesus, in Tunisia, and effect on the host. Annals of Tropical Medicine and Parasitology, 2000, 94 , 55-68.

Findlay G.M. \& MidDleton A.D. Epidemic disease among voles (Microtus) with special reference to Toxoplasma. Journal of Animal Ecology, 1934, 3, 150-160.

Geisel O., Kaiser E., Krampitz H.E. \& Rommel M. Beiträge zum Lebenszyklus der Frenkelien. IV. Pathomorphologische Befunde an den organen experimentell infizierter Rötelmäuse. Veterinarian Pathology, 1978, 15, 621-630.

Giraudoux P. Utilisation de l'espace par les hôtes du ténia multiloculaire (Echinococcus multilocularis) : conséquences épidémiologiques. Ph.D. Thesis, University of Dijon, France, 1991, $106 \mathrm{p}$.

Giraudoux P., Delattre P., Habert M., Quéré J.P., Deblay S., Defaut R., Duhamel R., Moissenet M.F., Salvi D. \& TruCHETET D. Population dynamics of fossorial water vole (Arvicola terrestris scherman): a land use and landscape perspective. Agriculture, Ecosystem and Environment, 1997, 66, 47-60

Godeluck B., Duplantier J.M., Ba K. \& Trape J.F. A longitudinal survey of Borrelia crocidurae prevalence in rodents and insectivores in Senegal. American Journal of Tropical Medicine and Hygiene, 1994, 50, 165-168.

Holmes J.C. Impact of infectious disease agents on the population growth and geographical distribution of animals. In: Population biology of infectious diseases, Anderson R.M. \& May R.M. (eds), Springer-Verlag, New York, 1982, 3751.

Hoogenboom I. \& Dijkstra C. Sarcocystis cernae: a parasite increasing the risk of predation of its intermediate host, Microtus arvalis. Oecologia, 1987, 74, 86-92.

Jäkel T., Khoprasert Y., Endepols S., Archer-Baumann C., Suasa-ard K., Promkerd P., Kliemt D., Boonsong P. \& HonGNARK S. Biological control of rodents using Sarcocystis singaporensis. International Journal for Parasitology, 1999, 29, 1321-1330.

Kia E.B., Delattre P., Giraudoux P., Quéré J.P. \& Ashford R.W. Natural infection of water vole Arvicola terrestris with Toxoplasma gondii in Jura plateau, eastern France. Annals of Tropical Medicine and Parasitology (in press).

Kleinbaum D.G. \& Klein M. Logistic regression. A self-learning text. 2 Edn. Springer-Verlag, New York, 2002.

LaArman J.J., Tadros W. \& Marks J. Studies on frenkeliosis and Frenkelia-induced coccidiosis in the Netherlands. Tropical and Geographical Medicine, 1979, 31, 167-168.

Legendre P. \& Legendre L. Numerical Ecology. Elsevier, Amsterdam, 1998

Le Pesteur M.H., Giraudoux P., Delattre P., Damange J.P. \& QUÉRÉ J.P. Spatiotemporal distribution of four species of cestodes in a landscape of mid-altitude mountains (Jura, France). Annales de Parasitologie Humaine et Comparée, 1992, 67, 155-160.

LORD R.D. The lens as an indicator of age in cottontail rabbits. Journal of Wildlife Management, 1959, 23, 359-360.

Martinet L. Détermination de l'âge chez le Campagnol des champs (Microtus arvalis (Pallas)) par la pesée du cristallin. Mammalia, 1966, 30, 425-430. 
Mills J.N., Ellis B.A., McKee K.T., Calderon G.E., Maiztegui J.I., Nelson G.O., Ksiazek T.G., Peters C.J. \& Childs J. A longituninal study of Junin virus activity in the rodent reservoir of Argentine hemorrhagic fever. American Joumal of Tropical Medicine and Hygiene, 1992, 47, 749-763.

Mills J.N., Childs J., Ksiazek T.G., Peters C.J. \& Velleca W.M. Methods for trapping and sampling small mammals for virologic testing. Centers for Disease Control and Prevention, Atlanta, 1995.

Morris P. A review of mammalian age determination methods. Mammal Review, 1971, 2, 69-104.

Rommel M. \& Krampitz H.E. Beiträge zum Lebenszyklus der Frenkelien. I. Die Identität von Isospora buteonis aus dem Mäusebussard mit einer Frenkelienart ( $F$. clethrionomyobuteonis spec. n.) aus der Rötelmaus. Berliner und Münchener Tierärztliche Wochenschrift, 1975, 88, 338-340.

SOKAL R. R. \& RohlF F. J. Biometry. W.H. Freeman \& Co, NewYork, 1998.

Soveri T., Henttonen H., Rudbäck E., Schildt R., Tanskanen R., Husu-Kallio J., Haukisalmi V., Sukura A. \& Laakkonen J. Disease patterns in field and bank vole populations during a cyclic decline in central Finland. Comparative Immunology Microbiology and Infectious Diseases, 2000, 23, 7389.

Spitz F., Le louarn H., Poulet A. \& Dassonville B. Standardisation des piégeages en ligne pour quelques espèces de rongeurs. Revue d'Écologie (Terre et Vie), 1974, 24, 564578.

TADros W., Bird R.G. \& Ellis D.S. The fine structure of cysts of Frenkelia (the M-organism). Folia Parasitologica, Praba, 1972, 19, 203-209.

TAdros W. \& LaARman J.J. Sarcocystis and related coccidian parasites: a brief general review, together with a discussion on some biological aspects of their life cycles and a new proposal for their classification. Acta Leidensia, 1976, 44, 1-107.

TAdros W. \& LAarman J.J. Apparent congenital transmission of Frenkelia (Coccidiai: Eimeriidae): first recorded incidence. Zeitschrift für Parasitenkunde, 1978, 58, 41-46.

Tadros W. \& LaArman J.J. Current concepts on the biology, evolution and taxonomy of tissue cyst-forming eimeriid coccidia. Advances in Parasitology, 1982, 20, 293-468.

Turner C.M.R. Seasonal and age distribution of Babesia, Hepatozoon, Trypanosoma and Grahamella species in Cletbrionomys glareolus and Apodemus sylvaticus populations. Parasitology, 1986, 93, 279-289.

Vorísek P., Votypka J., Zvára K. \& Svobodová M. Heteroxenous coccidia increase the predation risk of parasitized rodents. Parasitology, 1998, 117, 521-524.

WigER R. Some pathological effects of endoparasites on rodents with special reference to the population ecology of microtines. Oikos, 1977, 29, 598-606.

Reçu le 11 décembre 2003 Accepté le 16 juin 2004 